慶應義塾大学学術情報リポジトリ

Keio Associated Repository of Academic resouces

\begin{tabular}{|c|l|}
\hline Title & Delayed production of free radicals following noise exposure. \\
\hline Sub Title & 音響外傷後のフリーラジカルの遅発性発現 \\
\hline Author & 山下, 大介(Yamashita, Daisuke) \\
\hline Publisher & 慶應医学会 \\
\hline Publication year & 2005 \\
\hline Jtitle & 慶應医学 (Journal of the Keio Medical Society). Vol.82, No.2 (2005. 6),p.21- \\
\hline JaLC DOI & \\
\hline Abstract & \\
\hline Notes & 号外 \\
\hline Genre & Journal Article \\
\hline URL & https://koara.lib.keio.ac.jp/xoonips/modules/xoonips/detail.php?koara_id=AN00069296-2005060 \\
& 2-0021 \\
\hline
\end{tabular}

慶應義塾大学学術情報リポジトリ(KOARA)に掲載されているコンテンツの著作権は、それぞれの著作者、学会または出版社/発行者に帰属し、その権利は著作権法によって 保護されています。引用にあたっては、著作権法を遵守してご利用ください。

The copyrights of content available on the KeiO Associated Repository of Academic resources (KOARA) belong to the respective authors, academic societies, or publishers/issuers, and these rights are protected by the Japanese Copyright Act. When quoting the content, please follow the Japanese copyright act. 


\title{
Delayed production of free radicals following noise exposure.
}

\author{
（音響外傷後のフリーラジカルの遅発性発現）
}

\section{山下大介}

\section{内容の要旨}

音響外傷による内耳有毛細胞の障害のメカニズムには、音そのもの による直接的・機械的ダメージと種々の代謝的ダメージがある。代謝 的障害の中には活性酸素やフリーラジカルが、内耳における細胞死に 重要な役割を持つと考えられている。しかし一般的にフリーラジカル の反忘はin vitroにおいては数ミリ秒と速いものであり、音響曝露後に 持続して生じる後発性の蝸牛障害を説明できるものではない。そこで 今回我々は、有色モルモットに音響負荷し（120dB SPL，4 kHz OBN, $5 \mathrm{~h}) 、 そ の$ 後の聴覚機能 (ABR : 聴性脳幹反応) および細胞死の形態 変化を経時的に観察し、さらにフリーラジカルの発現を活性酸素の マーカー（4-HNE）および活性窒素のマーカー（Nitrotyrosine）を用い て免度組織学的に検郡した。

このモデルにおける聴覚機能は、負荷後 7 日目で固定化し、難聴の 残存するPTS (permanent threshold shift : 永続的闌值上昇)を呈してい た。細胞死の形態変化も同様に $7 \sim 10$ 日目で固定化していた。これに 対して、免疫組織学的には $7 \sim 10$ 日目に活性酸素·活性窒素共に外有 毛細胞での発現のピークを確認した。この結果は機能的・形態的変化 と一致するものであり、音響曝露後、持続する代謝的障害を示唆する ものと考えられた。

音響曝露後、形態的には徐々に障害が増加・拡大するのに対し、聴 覚機能は音響負荷後に闇值が最大值を示し、その後、徐々に減少し、 7 日目に固定している。この最初の閵值上昇は、様々な蝸牛における 可逆的な構造の変化によると考えられる。例えば、基底膜の機械的な コンプライアンスの変化や、有毛細胞の感覚毛のスティッフネスの減 少、求心性神経終末の興奮毒性などである。最終的な内耳組織障害の 程度は、この遅発性に生じるフリーラジカルの負の要素と可逆的な構 造変化の正の要素によるバランスにより決定されていると考えられ た。

遅発性のフリーラジカルの発現のメカニズムとして我々の仮説は、 最初に障害を受けた部位 ( $4 \mathrm{kHz}$ 領域)より種々のケミカルメディエー ター（これには活性酸素やフリーラジカルも含まれる）が放出され、 周囲の隣接細胞に影響を及ぼし、その隣接細胞内でまた種々の反応に より細胞死（これにはアポトーシスやネクローシスも含まれる）が誘 導され、またその隣の細胞にとダメージが空間的・時間的に拡大する のではというものである。この結果に基づき音響曝露後から、種々の スカペンジャーの投与によって音響外傷性難聴を防御できる可能性 が示唆された。

\section{論文審査の要旨}

音響性聴器障害による内耳性難聴は感音難聴の主な原因の一つ で、その多くが難治性である。本研究の目的は、強大音響曝露によ り内耳螖牛に生じる病態生理的、形態的、生化学的変化を解明する ことである。有色モルモットに強大音響を負荷し（120dB SPL, $4 \mathrm{kHz}$ OBN, 5h) 、その後の聴覚機能（ABR：聴性脳幹反応）および細胞死 の形態変化を経時的に観察し、さらにフリーラジカルの発現を活性 酸素のマーカー (4-HNE) おょび活性窒素のマーカー

(Nitrotyrosine) を用いて免疫組織学的に検討した。聴覚機能は、強 大音響負荷後 7 日目で固定化し、不可逆的難聴の所見と考えられる 永続的閾值上昇 (PTS) を呈した。細胞死の形態変化も同様に 7 10日目で固定化した。これに対して、免疫組織学的には $7 \sim 10$ 日目 に外有毛細胞で活性酸素・活性窒素の各マーカーが発現のピークを 示した。この結果は機能的・形態的変化と一致するものであり、音 響暴露後にも外有毛細胞内で代謝的障害が進行する可能性が示唆さ れた。

審查ではまず、生理的な状態での蝸牛における環境に関して質問 がなされた。螖牛は日常において騒音を含め、様々なストレスに曝 露されており、組織内での酸化ストレスと内因性の抗酸化作用との バランスで障害のレベルが決まると考えられている。また基礎実験 での報告では、中等度の音響を持続的に曝露することによって、内 因性の抗酸化作用を誘導することにより、強大音響に曝露された際 に螖牛保護効果を呈する機構 (sound conditioning) があると回答さ れた。次に、蝸牛とiNOSの関与に対する質問に対し、有毛細胞や外 側壁でのiNOSの局在に関する報告があると回答された。また、周波 数別に聴覚閾値と有毛細胞の形態変化に相関があるかと質問され た。これに対しては、蝸牛の頂回転側と基底回転側の有毛細胞での 酸化ストレスに対する感受性に差があり（基底回転側の有毛細胞が 酸化ストレスに対してより脆弱）、必ずしも同等のストレスに対し 障害の程度は一致しないこと、また、形態的には残存する細胞が機 能していない可能性や、逆に形態的な細胞死が多い場合でも、残存 する細胞が過剩に機能する可能性などが考えられ、必ずしも機能的 な聴覚閾值と形態的な有毛細胞死の数に相関は見られないと回答さ れた。最後に臨床态用に関して、現在臨床で用いられているステロ イド剤などとの効果の比較について質問がなされ、現状での基礎実 験では種々の抗酸化剤やフリーラジカルスカベンジャーとステロイ ド剤での蝸牛保護効果には大きな差がないと回答された。

以上のように、本研究は臨床応用を含めて今後の検討課題は残し ているものの、強大音響暴露後にも進行する代謝的障害と活性酸 素・活性窒素との関与を明らかにした点で有意義な研究であると評 価された。

論文審查担当者 主査 耳鼻咽喉科学 小川 郁 生理学 岡野 栄之 解剖学 仲嶋 一範 医化学 末松 誠

学力確認担当者:

審查委員長 : 岡野 栄之 